\title{
Pengaruh Ukuran Partikel Sulfur terhadap Mortalitas, Pertumbuhan dan Perkembangan Ulat Grayak Jagung Spodoptera frugiperda J. E. Smith (Lepidoptera: Noctuidae)
}

\author{
Fadhilah Rahmah Aprianti ${ }^{1,2}$, Yusup Hidayat ${ }^{3}$, dan Danar Dono ${ }^{3}$ \\ ${ }^{1}$ Program Studi Agronomi, Fakultas Pertanian, Universitas Padjadjaran \\ ${ }^{2}$ Direktorat Perlindungan Tanaman Pangan, Direktorat Jenderal Tanaman Pangan, \\ Kementerian Pertanian \\ ${ }^{3}$ Departemen Hama dan Penyakit Tumbuhan, Fakultas Pertanian, Universitas Padjadjaran \\ Jl. Raya Bandung-Sumedang Km 21 \\ *Alamat korespondensi: fadhilah19004@mail.unpad.ac.id
}

\begin{tabular}{lrc}
\hline \multicolumn{2}{c}{ INFO ARTIKEL } & ABSTRACT/ABSTRAK \\
\hline Diterima: & $16-08-2021$ & \\
Direvisi: & $17-11-2021$ & The Effect of Sulphur Particle Size on Mortality, Growth and \\
Dipublikasi:23-01-2022 & Development of Fall Armyworm Spodoptera Frugiperda J. E. Smith \\
& (Lepidoptera: Noctuidae)
\end{tabular}

Keywords:

Contact pesticide, Insect control, Natural pesticide, Mineral formulation

Kata Kunci:

Formulasi mineral, Pengendalian serangga hama, Pestisida alami, Pestisida kontak
Spodoptera frugiperda is a new pest of maize in Indonesia. This insect pest attacks maize leaf and also the growing point. The farmers generally use synthetic insecticide to control $S$. frugiperda. Saver alternative of the control is the use of natural insecticide. Study was aimed to examine the effect of sulphur mineral particle size on $S$. frugiperda. Randomized Block Design (RBD) was used in this study. The treatments were five sizes of sulphur formulation particles $(100,200,300,400$, and 500 mesh) and applied at the concentration of $4 \%$. Water and wetting agent + dispersant agent were used as controls. Mineral suspension was applied to $S$. frugiperda larvae by spraying. Each treatment was replicated four times. The result showed that the application of sulphur at the size of 500 mesh $(25 \mu \mathrm{m})$ resulted in larval mortality of $S$. frugiperda at 48 hours - 24 days after treatment $(11,25 \%$ $33,75 \%)$ which were significantly different from the mortality in control $(0,00 \%)$. However, all the tested particle sizes of sulphur did not affect the development and pupal weight of $S$. frugiperda. In addition, sulphur mineral particles at the sizes of 100,400 , and 500 mesh were able to reduce the emergence of normal adults of $S$. frugiperda from 16,25 adults in control to $11,25,10,50$, and 10,75 adults respectively.

Spodoptera frugiperda merupakan hama baru pada pertanaman jagung di Indonesia. Serangga hama ini menyerang pada bagian daun dan juga titik tumbuh tanaman jagung. Petani umumnya menggunakan insektisida sintetik untuk mengendalikan $S$. frugiperda. Alternatif pengendalian lainnya yang lebih aman yaitu dengan menggunakan insektisida bahan alam. Penelitian ini bertujuan untuk menguji pengaruh ukuran partikel mineral sulfur terhadap $S$. frugiperda. Metode penelitian yang digunakan yaitu metode percobaan dengan Rancangan Acak Kelompok. Perlakuan yang diuji yaitu lima ukuran partikel formulasi mineral sulfur (100, 200, 300, 400, dan 500 mesh) masingmasing pada konsentrasi 4\%. Air dan wetting agent + dispersant agent masing-masing digunakan sebagai kontrol. Formulasi mineral diaplikasikan ke larva $S$. frugiperda dengan cara disemprotkan. Setiap perlakuan diulang sebanyak empat kali. Hasil percobaan menunjukkan bahwa pengaplikasian 
sulfur dengan ukuran mesh $500(25 \mu \mathrm{m})$ dapat menyebabkan mortalitas larva S. frugiperda pada 1 hari - 24 hari setelah perlakuan (11,25\% - 33,75\%) yang berbeda nyata dengan kontrol $(0,00 \%)$. Namun, berbagai ukuran partikel mineral sulfur yang diuji tidak memengaruhi lama perkembangan larva dan berat pupa $S$. frugiperda. Sementara itu, perlakuan mineral sulfur ukuran 100, 400, dan 500 mesh mampu menurunkan jumlah imago normal $S$. frugiperda dari 16,25 ekor pada kontrol menjadi 11,25, 10,50, dan 10,75 ekor.

\section{PENDAHULUAN}

Jagung merupakan komoditas pangan yang sangat penting di Indonesia. Selain sebagai sumber karbohidrat, jagung juga penting sebagai bahan baku industri pangan dan pakan ternak (Suarni \& Yasin, 2015; Utomo, 2012). Pada tahun 2018 produksi jagung Indonesia mencapai 30.253.938 ton dengan luas panen 5.680 .360 ha (FAOSTAT, 2020). Perkembangan permintaan jagung diduga akan terus meningkat. Diperkirakan lebih dari 60\% kebutuhan jagung dalam negeri digunakan untuk pakan, sedangkan konsumsi pangan hanya sekitar 24\%, sisanya untuk kebutuhan industri lainnya dan benih (14\%) (Kementerian Pertanian, 2020). Perkembangan jagung di Indonesia diarahkan untuk mewujudkan Indonesia menjadi produsen jagung yang tangguh dan mandiri (Syuryawati dkk., 2014).

Untuk meningkatkan produktivitas, pengendalian Organisme Pengganggu Tanaman (OPT) sangat berperan dalam suksesnya budidaya jagung tersebut. Terdapat beberapa OPT utama yang menyerang tanaman jagung di Indonesia, salah satunya ulat grayak jagung Spodoptera frugiperda J.E. Smith (Lepidoptera: Noctuidae) atau dikenal dengan Fall Armyworm (FAW). FAW ditemukan sebagai serangga asli di wilayah tropis di benua Amerika, memanjang dari Amerika Serikat hingga Argentina (Capinera, 2017).

Saat ini, $S$. frugiperda dikenal sebagai salah satu hama dari tanaman jagung di beberapa tempat di Indonesia. Tahun 2019, hama ini dilaporkan menyerang pertanaman jagung di beberapa wilayah di Indonesia seperti Provinsi Sumatera Utara, Lampung, Banten dan Jawa Barat, serta Kalimantan Utara (Lestari dkk., 2020; Nonci dkk., 2019; Sartiami dkk., 2020; Subiono, 2019). Berbagai cara pengendalian FAW telah dikembangkan, termasuk insektisida bahan alam.

Bahan baku insektisida alami dapat berupa metabolit sekunder tanaman, mineral dan entomopatogen (Glenn \& Puterka, 2010; Prayogo, 2017; Saenong, 2017). Sulfur merupakan salah satu jenis mineral yang sejak dulu sudah digunakan untuk pengendalian serangga hama. Mineral sulfur saat ini terdaftar sebagai bahan baku yang diijinkan untuk digunakan sebagai insektisida, akarisida, dan fungisida (USDA, 2017).

Sulfur merupakan salah satu mineral padatan yang tidak berbau, tidak berasa, berwarna kuning pucat, konduktor listrik yang lemah, dan tidak larut pada air. Sulfur diduga merupakan pestisida tertua yang hingga saat ini masih digunakan (Williams \& Cooper, 2004). Sebelum ditemukannya pestisida sintetik, sulfur banyak digunakan sebagai pengendali organisme pengganggu tanaman (Subiyakto dkk., 2016).

Sulfur dilaporkan dapat digunakan untuk mengendalikan $S$. frugiperda dan sejumlah spesies serangga hama. Berdasarkan penelitian Guerreiro et al. (2013), penambahan mineral sulfur dalam formulasi insektisida sintetik dapat meningkatkan mortalitas larva $S$. frugiperda. Kandungan sulfur pada bentonite juga diduga berkontribusi terhadap mortalitas pada larva $S$. frugiperda (Constanski et al., 2016). Lebih jauh, tepung sulfur yang diaplikasikan pada buah blueberry menyebabkan kematian yang signifikan pada imago jantan dan betina Drosophilla suzukii Matsumura (Diptera: Drosophilidae) (PérezGuerrero \& Molina, 2016).

Pada penelitian lainnya, Gardner-Gee (2013) melaporkan bahwa sulfur secara tunggal dapat menekan peningkatan populasi Bactericera cockerelli Suic (Hemiptera: Triozidae). Selain itu, sulfur dilaporkan menyebabkan kematian terhadap kumbang beras Sitophilus oryzae L. (Coleoptera: Curculionidae) dan kumbang tepung Tribolium confusum du Val (Coleoptera: Tenebrionidae) serta kumbang Tribolium castaneum Herbst. (Coleoptera: Tenebrionidae) (Oktianty dkk., 2016; Riudavets et al., 2013).

Hasil penelitian sebelumnya menunjukkan bahwa ukuran partikel mineral berpengaruh terhadap keefektifannya dalam mengendalikan serangga hama. Berdasarkan penelitian Alkan et al. (2019) pengaplikasian tanah diatomik (diatomaceous 
earth) ukuran partikel $\leq 10 \mu \mathrm{m}$ menyebabkan kematian yang signifikan terhadap larva Tenebrio molitor L. (Coleoptera: Tenebrionidae). Lebih jauh, Hua et al. (2015) kalsium karbonat berukuran nano efektif mengurangi serangan lalat buah Bactrocera dorsalis Hendel (Diptera: Tephritidae) dibandingkan dengan koloid kalsium karbonat. Sampai saat ini, belum ada laporan mengenai efek berbagai ukuran partikel mineral sulfur terhadap $S$. frugiperda. Oleh karena itu, penelitian ini bertujuan untuk menguji pengaruh berbagai ukuran partikel mineral sulfur terhadap mortalitas, pertumbuhan dan perkembangan $S$. frugiperda.

\section{BAHAN DAN METODE}

\section{Penyiapan Formulasi Mineral Sulfur}

Mineral sulfur yang digunakan yaitu berbentuk tepung. Sebelum pembuatan formulasi, sulfur disaring dengan saringan berukuran 100 (149 $\mu \mathrm{m}), 200$ (74 $\mu \mathrm{m}), 300(44 \mu \mathrm{m}), 400(37 \mu \mathrm{m})$, dan 500 mesh $(25 \mu \mathrm{m})$. Penyaringan/pengayakan merupakan metode untuk mengkategorikan ukuran partikel bubuk yang melewati lapisan saringan yang memiliki ukuran tertentu (ESPI Metals, 2017). Sebelum digunakan, sulfur hasil penyaringan disimpan di dalam stoples kedap udara yang telah diberi label dan disimpan pada suhu ruangan. Formulasi mineral dibuat dengan cara mencampurkan mineral sulfur (90\%), wetting agent Sodium Lauryl Sulfate (Texapon) (5\%) dan dispersant agent Sodium naphthalene sulfonate formaldehyde condensates (DEMOL RN) (5\%). Suspensi mineral sulfur yang digunakan yaitu dengan konsentrasi $4 \%$ yang terdiri dari 3,6 g mineral sulfur, 0,2 g wetting agent, dan 0,2 $\mathrm{g}$ dispersant agent dalam $100 \mathrm{ml}$ air.

\section{Penyiapan Serangga Uji}

Serangga uji yang digunakan yaitu larva $S$. frugiperda yang diperoleh dari pertanaman jagung di Majalengka Wetan, Kabupten Majalengka, Jawa Barat. Larva dipelihara di dalam kontainer plastik ukuran 36,5 cm x $29 \mathrm{~cm}$ x 7,5 cm beralas kertas tisu dan dibagian tutupnya diberikan kain kassa sebagai ventilasi dan diberi pakan jagung semi (baby corn). Larva instar akhir yang menjelang berpupa ditempatkan pada kontainer plastik $(36,5 \mathrm{~cm}$ x $29 \mathrm{~cm}$ x $15 \mathrm{~cm}$ ) yang berisi pasir halus untuk proses pupasi. Selanjutnya, pupa dipindahkan ke dalam kurungan massal berukuran $50 \mathrm{~cm}$ x $50 \mathrm{~cm}$ x $50 \mathrm{~cm}$.

Imago yang muncul diberi pakan berupa larutan madu $10 \%$ yang diserapkan pada segumpal kapas yang diikat dengan tali dan digantung dari permukaan atas kurungan. Imago dipelihara hingga bertelur. Imago meletakkan telur pada daun jagung yang diletakkan di dalam kurungan. Telur yang sudah diletakkan pada daun jagung dipindahkan ke kontainer plastik ukuran $12 \mathrm{~cm}$ x $9 \mathrm{~cm}$ x $6 \mathrm{~cm}$ yang dialasi kertas tisu dan diberikan jagung semi sebagai pakan larva yang baru menetas. Serangga uji dipelihara dan diperbanyak hingga mencapai jumlah yang cukup untuk digunakan dalam perlakuan.

\section{Pengujian Pengaruh Ukuran Partikel Mineral Sulfur terhadap Larva $S$. frugiperda}

Larva instar kedua sebanyak 20 ekor disemprotkan dengan suspensi formulasi mineral sulfur $(20 \mathrm{ml})$ konsentrasi $4 \%$. Terdapat 5 perlakuan mineral yang diuji yaitu ukuran partikel 100, 200, 300, 400 dan 500 mesh. Sebagai pembanding, larva $S$. frugiperda disemprot dengan wetting agent + dispersant agent (WA+DA) (kontrol 1) dan air (kontrol 2).

Setelah disemprot, masing-masing larva dimasukkan ke dalam wadah plastik bertutup dan diberikan pakan jagung semi. Percobaan menggunakan Rancangan Acak Kelompok (RAK) dengan 4 kali pengulangan. Pengamatan dilakukan terhadap mortalitas larva, pertumbuhan dan perkembangan mencapai imago, dan berat pupa $S$. frugiperda.

Pengamatan mortalitas larva $S$. frugiperda dilakukan setiap hari sejak 1 hari setelah perlakuan hingga membentuk pupa. Mortalitas larva $S$. frugiperda dihitung dengan rumus: ((jumlah $S$. frugiperda yang mati)/jumlah $S$. frugiperda yang diuji) x 100\%. Pengamatan lama perkembangan larva dihitung dari saat perlakuan hingga terjadi pupasi. Sementara itu, lama perkembangan imago dihitung mulai dari pembentukan pupa hingga waktu kemunculan imago. Penghitungan berat pupa dilakukan dengan menimbang berat pupa pada saat 3 hari setelah pupa terbentuk.

\section{Analisis Statistik}

Data dianalisis dengan menggunakan Software Minitab versi 19. Pada tahap pertama, data terlebih dahulu diuji normalitas dan homogenitasnya. Jika data tidak homogen atau tidak normal maka data ditransformasi terlebih dahulu sebelum dilakukan uji ANOVA. Apabila terdapat perbedaan yang nyata di antara perlakuan, maka analisis dilanjutkan dengan Tukey's test. 


\section{HASIL DAN PEMBAHASAN}

Pengaruh Berbagai Ukuran Partikel Mineral Sulfur terhadap Mortalitas Larva Spodoptera frugiperda

Hasil percobaan menunjukkan bahwa pada pengamatan 1 hari setelah perlakuan (HSP), mineral sulfur (konsentrasi 4\%) tidak menunjukkan pengaruh yang nyata terhadap mortalitas larva $S$. frugiperda ( $\mathrm{F}$ $6,18=2,38 ; \mathrm{P}=0,072)$. Namun, pada pengamatan 2 HSP, pengaplikasian mineral sulfur ukuran partikel 500 mesh $(25 \mu \mathrm{m})$ berpengaruh nyata terhadap mortalitas larva $S$. frugiperda $(11,25 \%)\left(\mathrm{F}_{6,18}=4,66 ; \mathrm{P}\right.$ $=0,005$ ) (Tabel 1; Gambar 1). Begitupun pada pengamatan $7 \mathrm{HSP}$, pengaplikasian mineral sulfur ukuran 500 mesh menunjukkan pengaruh nyata terhadap mortalitas larva $S$. frugiperda $(18,75 \%)\left(\mathrm{F}_{6,18}\right.$ $=6,25 ; \mathrm{P}=0,001)$. Lebih lanjut, pada pengamatan 14 HSP, mortalitas larva $S$. frugiperda pada perlakuan berbagai ukuran partikel mineral sulfur berbeda nyata dengan kontrol ( $\mathrm{F} 6,18=9,32 ; \mathrm{P}=0,000)$. Pada pengamatan $24 \mathrm{HSP}$, pengaplikasian mineral sulfur ukuran mesh 100, 400, dan 500 berbeda nyata dengan kontrol ( $\left.\mathrm{F}_{6,18}=2,47 ; \mathrm{P}=0,001\right)$. Ketiga ukuran mesh tersebut menyebabkan mortalitas larva $S$. frugiperda masing-masing $25 \%$, $28,75 \%$, dan $33,75 \%$, sementara pada kontrol tidak terjadi mortalitas larva $S$. frugiperda.

Tabel 1. Mortalitas larva $S$. frugiperda yang disemprotkan sulfur dengan berbagai ukuran partikel mineral

\begin{tabular}{ccccccc}
\hline \multirow{2}{*}{$\begin{array}{c}\text { Perlakuan } \\
\text { (sulfur) }\end{array}$} & \multicolumn{5}{c}{ Mortalitas larva S. frugiperda (\%) \pm SE pada pengamatan } \\
\cline { 2 - 7 } & $1 \mathrm{HSP}$ & $2 \mathrm{HSP}$ & $7 \mathrm{HSP}$ & $14 \mathrm{HSP}$ & $21 \mathrm{HSP}$ & $24 \mathrm{HSP}$ \\
\hline Mesh 100 & $3,75 \pm 3,75 \mathrm{a}$ & $5,00 \pm 3,54 \mathrm{ab}$ & $8,75 \pm 7,18 \mathrm{ab}$ & $20,00 \pm 8,90 \mathrm{a}$ & $25,00 \pm 7,36 \mathrm{ab}$ & $25,00 \pm 7,36 \mathrm{a}$ \\
Mesh 200 & $0,00 \pm 0,00 \mathrm{a}$ & $1,25 \pm 1,25 \mathrm{ab}$ & $8,75 \pm 5,54 \mathrm{ab}$ & $15,00 \pm 4,56 \mathrm{a}$ & $16,25 \pm 5,54 \mathrm{bc}$ & $16,25 \pm 5,54 \mathrm{ab}$ \\
Mesh 300 & $1,25 \pm 1,25 \mathrm{a}$ & $2,50 \pm 2,50 \mathrm{ab}$ & $3,75 \pm 2,39 \mathrm{ab}$ & $16,25 \pm 3,75 \mathrm{a}$ & $21,25 \pm 4,73 \mathrm{ab}$ & $21,25 \pm 4,73 \mathrm{ab}$ \\
Mesh 400 & $1,25 \pm 1,25 \mathrm{a}$ & $6,25 \pm 1,25 \mathrm{ab}$ & $8,75 \pm 2,39 \mathrm{ab}$ & $21,25 \pm 4,27 \mathrm{a}$ & $27,50 \pm 2,04 \mathrm{ab}$ & $28,75 \pm 3,15 \mathrm{a}$ \\
Mesh 500 & $8,75 \pm 3,75 \mathrm{a}$ & $11,25 \pm 3,75 \mathrm{a}$ & $18,75 \pm 4,27 \mathrm{a}$ & $23,75 \pm 4,27 \mathrm{a}$ & $32,50 \pm 6,29 \mathrm{a}$ & $33,75 \pm 7,18 \mathrm{a}$ \\
WA + DA & $0,00 \pm 0,00 \mathrm{a}$ & $0,00 \pm 0,00 \mathrm{~b}$ & $0,00 \pm 0,00 \mathrm{~b}$ & $0,00 \pm 0,00 \mathrm{~b}$ & $0,00 \pm 0,00 \mathrm{c}$ & $0,00 \pm 0,00 \mathrm{~b}$ \\
Kontrol Air & $0,00 \pm 0,00 \mathrm{a}$ & $0,00 \pm 0,00 \mathrm{~b}$ & $0,00 \pm 0,00 \mathrm{~b}$ & $0,00 \pm 0,00 \mathrm{~b}$ & $0,00 \pm 0,00 \mathrm{c}$ & $0,00 \pm 0,00 \mathrm{~b}$
\end{tabular}

Keterangan: WA (wetting agent), DA (dispersant agent). HSP (hari setelah perlakuan). Angka-angka pada kolom yang sama yang diikuti dengan huruf yang sama menunjukkan tidak berbeda nyata pada level kepercayaan 95\% (Uji Tukey). Data mortalitas 1 HSP, 2 HSP, dan 7 HSP ditransformasi dengan SQUARE ROOT (SQRT(X+0,5)) dan data mortalitas 14 HSP ditransformasi dengan SQUARE ROOT (SQRT(X)) sebelum dianalisa dengan GLM ANOVA. Sulfur (mesh) pada konsentrasi 4\%.

Partikel mineral sulfur dapat menyebabkan mortalitas $S$. frugipeda. Hasil penelitian ini menunjukkan bahwa ukuran partikel mineral sulfur dapat memengaruhi tingkat mortalitas larva $S$. frugiperda. Mineral sulfur dengan ukuran partikel terkecil yaitu 500 mesh $(25 \mu \mathrm{m})$ secara konsisten mampu menyebabkan mortalitas $S$. frugiperda yang berbeda nyata dengan kontrol. Belum ada laporan sebelumnya mengenai penggunaan berbagai ukuran partikel mineral sulfur terhadap $S$. frugiperda dan serangga hama lainnya. Ukuran partikel mineral diduga berperan penting dalam mortalitas larva. Menurut Smith \& MacLeod (1943), semakin halus material mineral, maka semakin tinggi mortalitas yang ditimbulkannya. Berdasarkan penelitian Vayias et al. (2009) semakin banyaknya partikel kecil tanah diatomik, semakin besar peluang untuk menutupi permukaan serangga dan semakin besar toksisitas yang dihasilkan karena bertambahnya area kontak antara tubuh serangga dengan partikel tanah diatomik. Umumnya, efektivitas mineral dapat meningkat seiring dengan menurunnya ukuran partikel ke ukuran yang ideal 1-2 $\mu \mathrm{m}$ karena dapat meningkatkan peluang penempelannya pada kutikula serangga (Glenn et al., 1999). Berdasarkan penelitian Smith \& MacLeod (1943), pengaplikasian partikel mineral sulfur dengan ukuran 325 mesh (44 $\mu \mathrm{m})$ mampu menyebabkan mortalitas larva Colias eurytheme Boisduval (Lepidoptera: Pieridae) pada tanaman Alfafa. Pengaplikasian berbagai ukuran partikel mineral lainnya dalam mengendalikan serangga hama juga telah dilaporkan. Pengaplikasian tanah diatomik ukuran partikel $1-10 \quad \mu \mathrm{m}$ menyebabkan kematian yang lebih tinggi pada larva Tenebrio molitor L. (Coleoptera: Tenebrionidae) dibandingkan pada perlakuan dengan ukuran partikel yang lebih besar (Alkan et al., 2019). Selain itu, formulasi tanah diatomik (diatomaceous earth) dengan partikel yang kecil mampu menyebabkan mortalitas yang lebih tinggi terhadap Cryptolestes ferrugineus Stephens (Coleoptera: Cucujidae) dibandingkan partikel yang lebih besar (Korunić, 1997).

Saat ini, belum ada laporan mengenai bagaimana efek kontak partikel mineral sulfur terhadap larva $S$. frugiperda. Berdasarkan hasil 
pengamatan dengan menggunakan mikroskop digital (600x), partikel mineral sulfur yang diaplikasikan sebagian besar menempel pada permukaan tubuh larva $S$. frugiperda. Larva yang mati tampak kering, menghitam, dan berkerut. Mineral sulfur yang menempel pada permukaan larva diduga mengakibatkan abrasi mekanis pada lapisan lilin permukaan tubuh serangga sehingga memungkinkan terjadinya dehidrasi dan desikasi. Sulfur diduga menyebabkan pelunakan lapisan lilin (wax) yang baru terbentuk pada eksoskeleton serangga (USDA, 2017). Selain itu, partikel mineral sulfur diduga berpengaruh terhadap membuka dan menutupnya spirakel sehingga menghambat aliran udara dan meningkatkan kehilangan air. Kehilangan air yang berlebihan sebagai akibat terjadinya disfungsi spirakel yang dapat menyebabkan kematian pada arthropoda (USDA, 2017). Partikel mineral dapat menempel pada permukaan kutikula serangga yang dapat menghalangi spirakel, serta menyebabkan perubahan perilaku pada serangga (Glenn \& Puterka, 2010). Sampai saat ini, belum diketahui mekanisme pengaruh partikel mineral sulfur terhadap membuka dan menutupnya spirakel pada larva $S$. frugiperda maupun serangga lainnya.

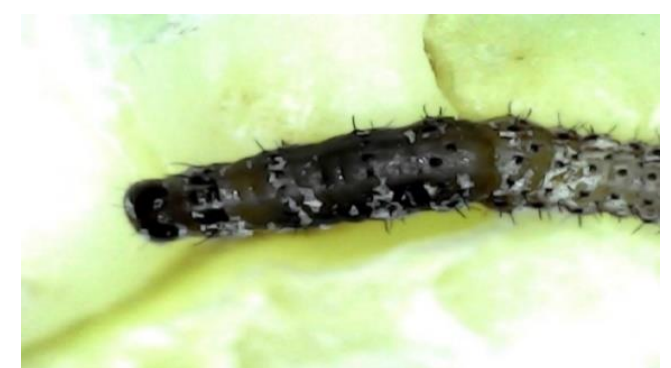

Gambar 1. Larva $S$. frugiperda yang mati satu hari setelah perlakuan pada perlakuan mineral sulfur mesh 500

Mineral sulfur sebagai insektisida racun perut (Smith \& MacLeod, 1943). Berdasarkan pengamatan, larva yang tidak mati selama 48 jam beberapa larva memiliki ukuran tubuh yang kecil dan tidak aktif bergerak dan akhirnya mati, menghitam dan membusuk. Hal ini diduga karena adanya gangguan pada aktivitas makan larva. Partikel mineral sulfur yang menempel pada tubuh larva diduga menempel pada permukaan jagung dan termakan oleh larva. Sulfur beracun apabila tertelan oleh larva tertentu (Dickinson et al., 1941). Studi mengenai gangguan aktivitas makan larva yang diakibatkan mineral sulfur dilaporkan pada penelitian Dickinson et al. (1941) dimana sulfur yang termakan larva $S$. frugiperda menyebabkan larva tidak aktif bergerak dan terjadi konstipasi. Disamping itu, pada serangga hama lainnya, larva Colias eurytheme (Lepidoptera: Pieridae) yang bertahan hidup setelah diaplikasikan sulfur menjadi tidak aktif bergerak dan berhenti makan sehingga menyebabkan tubuh larva menyusut (Smith \& MacLeod, 1943). Selain itu, sulfur mampu mematikan larva Malacosoma americana Fabricius (Lepidoptera: Lasiocampidae) setelah memakan daun yang diberi perlakuan sulfur (Macleod, 1937).

\section{Pengaruh Berbagai Ukuran Partikel Mineral terhadap Lama Perkembangan $S$. frugiperda}

Hasil pengamatan menunjukkan bahwa perlakuan berbagai ukuran mineral sulfur tidak berpengaruh nyata terhadap lama stadia perkembangan $S$. frugiperda (Tabel 2). Hasil pengamatan lama stadia larva pada perlakuan berbagai ukuran mineral sulfur tidak berpengaruh nyata terhadap kedua kontrol $\left(\mathrm{F}_{6,18}=0,70 ; \mathrm{P}=0,651\right)$. Sama halnya dengan hasil pengamatan pada perkembangan pupa $\left(\mathrm{F}_{6,18}=1,06 ; \mathrm{P}=0,419\right)$ dan perkembangan larva-pupa $\left(\mathrm{F}_{6,18}=2,64 ; \mathrm{P}=0,052\right)$. Berdasarkan hasil pengamatan, pengaplikasian mineral sulfur dengan berbagai ukuran partikel tidak mengganggu lama perkembangan $S$. frugiperda. Larva $S$. frugiperda yang bertahan hidup, mampu menyelesaikan proses perkembangannya hingga mencapai imago. Namun demikian, ditemukan larva $S$. frugiperda yang tidak berkembang dengan normal (terdapat gangguan dalam proses perubahan instar) sehingga terjadi keterlambatan dalam perkembangan larva $S$. frugiperda. Hal ini diduga karena adanya gangguan pada metabolisme larva. Sulfur dapat menyebabkan kerusakan organ penghasil energi pada serangga (Bonne et al., 2017). Larva tampak berukuran kecil dan mengalami keterlambatan dalam proses pergantian kulit dibandingkan larva lainnya. Hal ini diduga adanya gangguan pada corpus allatum atau corpora allata dalam pembentukan prothoracic gland hormone untuk proses ekdisis. Menurut Kuribayashi (1988) sulfur mampu menyebabkan gangguan proses ganti kulit (ekdisis) pada larva ulat sutera tanaman mulberi. Walaupun terdapat gangguan pada proses tersebut, tidak menyebabkan gangguan pada total durasi larva $S$. frugiperda. Bertolak belakang dengan hasil studi pada serangga hama lainnya yaitu mineral sulfur mampu menyebabkan melambatnya proses perkembangan larva D. melanogaster Meigen (Diptera: Drosophilidae) sehingga meningkatkan total durasi larva (Das et al., 2010). 
Tabel 2. Lama stadia perkembangan $S$. frugiperda yang stadia larvanya disemprotkan sulfur dengan berbagai ukuran partikel (mesh) pada konsentrasi $4 \%$

\begin{tabular}{lccc}
\hline \multirow{2}{*}{ Perlakuan (sulfur) } & \multicolumn{3}{c}{ Lama stadia perkembangan $S$. frugiperda (hari) \pm SE pada stadia } \\
\cline { 2 - 4 } & Larva* $^{*}$ & Pupa & Larva - Pupa \\
\hline Mesh 100 & $12,00 \pm 0,41 \mathrm{a}$ & $10,00 \pm 0,58 \mathrm{a}$ & $22,00 \pm 0,41 \mathrm{a}$ \\
Mesh 200 & $11,75 \pm 0,25 \mathrm{a}$ & $9,75 \pm 0,48 \mathrm{a}$ & $21,50 \pm 0,50 \mathrm{a}$ \\
Mesh 300 & $12,25 \pm 0,25 \mathrm{a}$ & $10,00 \pm 0,41 \mathrm{a}$ & $22,25 \pm 0,25 \mathrm{a}$ \\
Mesh 400 & $12,25 \pm 0,25 \mathrm{a}$ & $11,00 \pm 0,29 \mathrm{a}$ & $23,25 \pm 0,48 \mathrm{a}$ \\
Mesh 500 & $11,75 \pm 0,25 \mathrm{a}$ & $9,75 \pm 0,25 \mathrm{a}$ & $21,50 \pm 0,29 \mathrm{a}$ \\
WA + DA & $11,75 \pm 0,25 \mathrm{a}$ & $9,50 \pm 0,50 \mathrm{a}$ & $21,25 \pm 0,25 \mathrm{a}$ \\
Kontrol Air & $11,75 \pm 0,25 \mathrm{a}$ & $9,50 \pm 0,65 \mathrm{a}$ & $21,25 \pm 0,48 \mathrm{a}$ \\
\hline
\end{tabular}

Keterangan: WA (wetting agent), DA (dispersant agent). Angka-angka pada kolom yang sama yang diikuti dengan huruf yang sama menunjukkan tidak berbeda nyata pada level kepercayaan 95\% (Uji Tukey). *stadia larva termasuk prepupa.

\section{Pengaruh Berbagai Ukuran Partikel Mineral Sulfur terhadap Berat Pupa $S$. frugiperda}

Berdasarkan hasil pengamatan tidak terdapat pengaruh nyata dari perlakuan ukuran mineral terhadap berat pupa $S$. frugiperda $\left(\mathrm{F}_{6,18}=1,40 ; \mathrm{P}=\right.$ 0,269). Pada perlakuan ukuran partikel mineral sulfur yang terkecil (500 mesh), berat pupa adalah 0,1789 \pm 0,011 g. Sementara itu, pada kontrol air dan WA+DA masing-masing berat pupa yaitu 0,1933 $\pm 0,012 \mathrm{~g}$ dan $0,1726 \pm 0,009 \mathrm{~g}$.

Tabel 3. Berat Pupa $S$. frugiperda yang stadia larvanya disemprotkan sulfur dengan berbagai ukuran partikel (mesh) pada konsentrasi 4\%

\begin{tabular}{cc}
\hline $\begin{array}{c}\text { Perlakuan } \\
\text { (sulfur) }\end{array}$ & $\begin{array}{c}\text { Berat pupa } S \text {. frugiperda }(\mathrm{g}) \\
\text { (Rata-rata } \pm \mathrm{SE})\end{array}$ \\
\hline Mesh 100 & $0,1863 \pm 0,008 \mathrm{a}$ \\
Mesh 200 & $0,1818 \pm 0,011 \mathrm{a}$ \\
Mesh 300 & $0,1755 \pm 0,005 \mathrm{a}$ \\
Mesh 400 & $0,1822 \pm 0,005 \mathrm{a}$ \\
Mesh 500 & $0,1789 \pm 0,011 \mathrm{a}$ \\
WA + DA & $0,1726 \pm 0,009$ a \\
Kontrol Air & $0,1933 \pm 0,012$ a \\
\hline Keterangan: WA (wetting agent), DA (dispersant agent). Angka- \\
angka pada kolom yang sama yang diikuti dengan \\
huruf yang sama menunjukkan tidak berbeda nyata \\
pada level kepercayaan 95\% (Uji Tukey).
\end{tabular}

Berat pupa $S$. frugiperda pada perlakuan berbagai ukuran partikel tidak jauh berbeda dengan berat pupa pada kontrol air dan WA+DA. Hal ini mengindikasikan bahwa pengaplikasian mineral sulfur secara kontak tidak memengaruhi berat pupa $S$. frugiperda. Studi mengenai pengaruh mineral sulfur terhadap berat pupa serangga hama belum ada yang melaporkan. Namun demikian, mineral lainnya (kaolin) yang diaplikasikan pada daun jagung dilaporkan tidak memengaruhi hasil berat pupa $S$. frugiperda dan $S$. eridania (Lepidoptera: Noctuidae) (Constanski et al., 2016).

\section{Pengaruh Berbagai Ukuran Partikel Mineral terhadap Kemunculan Imago $S$. frugiperda}

Berdasarkan hasil pengamatan, pengaplikasian berbagai ukuran partikel mineral sulfur berpengaruh nyata terhadap kemunculan imago normal $S$. frugiperda $\left(\mathrm{F}_{6,18}=5,90 ; \mathrm{P}=0,002\right)$. Diantara semua ukuran partikel mineral sulfur yang diuji yang berpengaruh nyata terhadap kemunculan imago normal adalah ukuran 100, 400, dan 500 mesh. Pada ketiga perlakuan mineral tersebut, jumlah imago normal $S$. frugiperda yang muncul masing-masing adalah $11,25 \pm 1,03$ ekor; $10,50 \pm 1,04$ ekor; dan $10,75 \pm$ 1,25 ekor. Sementara itu, pada kontrol air dan $\mathrm{WA}+\mathrm{DA}$, jumlah imago normal yang muncul

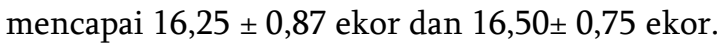

Pengaplikasian berbagai ukuran partikel mineral sulfur dapat memengaruhi kemunculan imago normal $S$. frugiperda. Larva yang diberi perlakuan mineral sulfur ukuran 100, 400, dan 500 mesh menghasilkan kemunculan imago normal $S$. frugiperda yang rendah dibandingkan perlakuan kontrol air dan WA+DA. Berdasarkan pengamatan yang dilakukan, ditemukan imago yang tidak normal mengalami kecacatan fisik seperti tidak sempurnanya pembentukan bagian sayap dimana sayap tampak lebih pendek dibandingkan panjang tubuhnya sehingga menyebabkan imago tidak dapat terbang (Gambar 2a). Selain itu, adanya kegagalan imago terhadap kemunculannya dari pupa. Imago tidak berhasil keluar dari pupa yang akhirnya imago mati di dalam pupa. Pupa yang mati tampak berwarna kehitaman dan keras (Gambar 2b). Hal ini diduga adanya kerusakan pada kelenjar penghasil pigmen kulit pupa (dekolorisasi). Laporan penelitian ini merupakan laporan pertama mengenai pengaruh 
ukuran partikel mineral sulfur terhadap kemunculan imago $S$. frugiperda dan serangga hama lainnya. Namun demikian, merujuk penelitian penggunaan bahan lainnya yakni partikel batu bara (coal) ukuran $\leq 38 \mu \mathrm{m}$ dapat menyebabkan kecacatan pada stadia larva, pupa, dan imago $T$. castaneum Herbst. (Coleoptera: Tenebrionidae) (Alcala-Orozco et al., 2020).

Tabel 4. Kemunculan imago $S$. frugiperda yang stadia larvanya disemprotkan sulfur dengan berbagai ukuran partikel (mesh) pada konsentrasi $4 \%$

\begin{tabular}{lccc}
\hline \multirow{2}{*}{ Perlakuan (sulfur) } & \multicolumn{3}{c}{ Pengaruh ukuran partikel sulfur terhadap kemunculan $S$. frugiperda (ekor) } \\
& \multicolumn{3}{c}{ \pm SE pada stadia } \\
\cline { 2 - 4 } & Imago normal & Imago tidak normal & Imago tidak muncul \\
\hline Mesh 100 & $11,25 \pm 1,03 \mathrm{c}$ & $1,00 \pm 0,41 \mathrm{a}$ & $2,75 \pm 1,18 \mathrm{a}$ \\
Mesh 200 & $13,75 \pm 1,44 \mathrm{abc}$ & $0,25 \pm 0,25 \mathrm{a}$ & $2,25 \pm 0,48 \mathrm{a}$ \\
Mesh 300 & $11,50 \pm 0,29 \mathrm{bc}$ & $1,00 \pm 0,58 \mathrm{a}$ & $2,75 \pm 0,25 \mathrm{a}$ \\
Mesh 400 & $10,50 \pm 1,04 \mathrm{c}$ & $1,00 \pm 0,41 \mathrm{a}$ & $2,50 \pm 1,04 \mathrm{a}$ \\
Mesh 500 & $10,75 \pm 1,25 \mathrm{c}$ & $0,50 \pm 0,29 \mathrm{a}$ & $2,75 \pm 0,85 \mathrm{a}$ \\
WA + DA & $16,50 \pm 0,75 \mathrm{ab}$ & $0,25 \pm 0,29 \mathrm{a}$ & $2,75 \pm 0,48 \mathrm{a}$ \\
Kontrol Air & $16,25 \pm 0,87 \mathrm{a}$ & $0,50 \pm 0,25 \mathrm{a}$ & $3,25 \pm 0,75 \mathrm{a}$ \\
\hline
\end{tabular}

Keterangan: WA (wetting agent), DA (dispersant agent). Angka-angka pada kolom yang sama yang diikuti dengan huruf yang sama menunjukkan tidak berbeda nyata pada level kepercayaan 95\% (Uji Tukey).
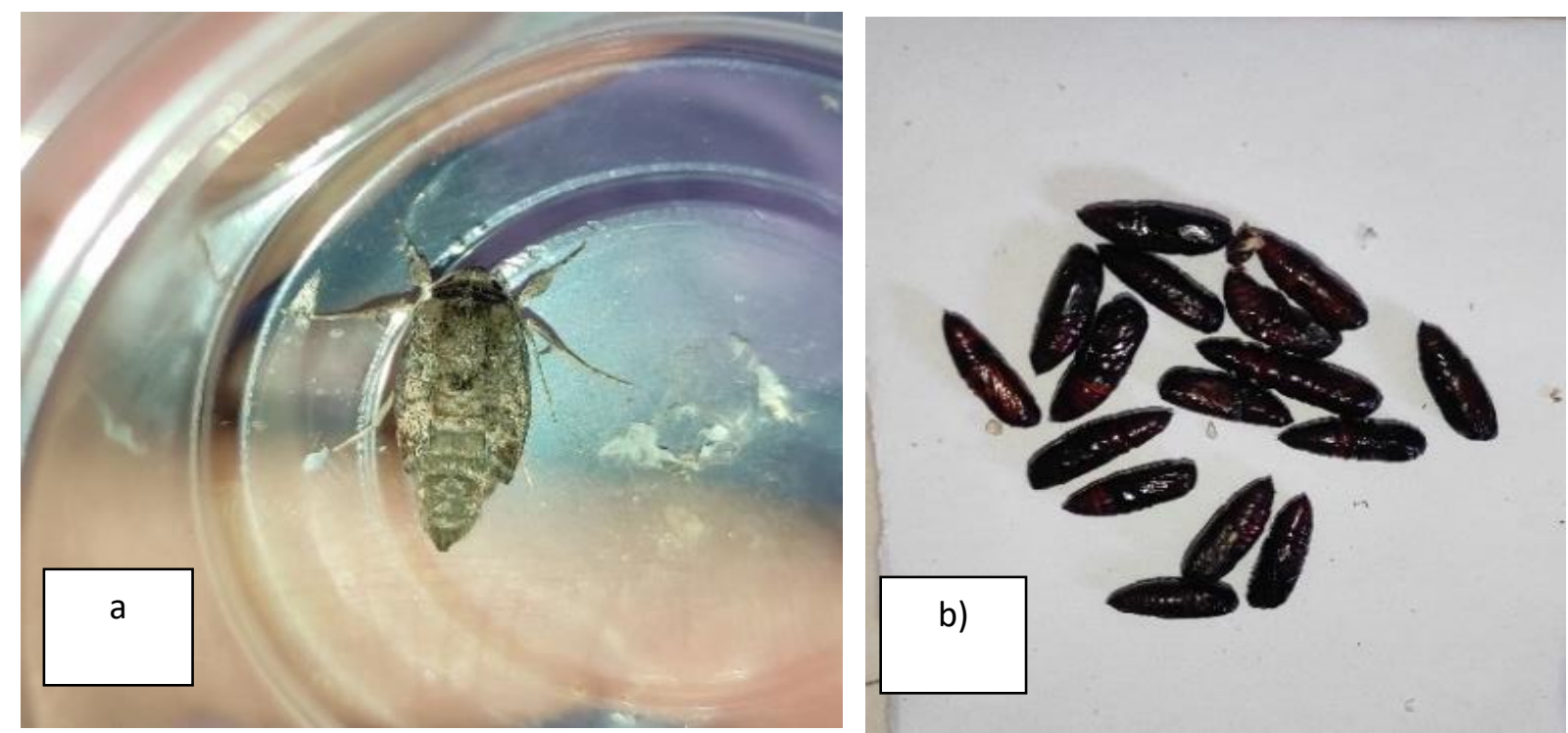

Gambar 2. Pengaruh pengaplikasian mineral sulfur terhadap imago dan pupa $S$. frugiperda. a) Imago $S$. frugiperda yang tidak normal. b) Pupa $S$. frugiperda yang mati

Penambahan sulfur ke dalam formulasi bahan aktif insektisida sintetik dilaporkan mampu meningkatkan keefektifan insektisida tersebut dalam mengendalikan serangga hama. Menurut penelitian Netto (2020) bahwa penambahan sulfur ke dalam formulasi insektisida spinosad dapat menyebabkan mortalitas larva $S$. frugiperda yang lebih tinggi dibandingkan dengan hanya insektisida spinosad saja. Lebih lanjut, penambahan sulfur ke dalam formulasi insektisida klorantraniliprol, triflumuron, dan flubendiamide dapat memperpanjang efek formulasi insektisida tersebut (Guerreiro et al., 2013). Namun demikian, belum ada laporan mengenai efek langsung dari sulfur yang diaplikasikan secara tunggal ke larva $S$. frugiperda terhadap mortalitas larva tersebut.

Berdasarkan penelitian ini, tingkat mortalitas larva $S$. frugiperda yang disemprot berbagai ukuran partikel mineral sulfur tidak melebihi 50\%. Walaupun demikian, dari penelitian ini diketahui bahwa sulfur dengan ukuran partikel paling kecil (500 mesh) cenderung lebih efektif dari pada ukuran partikel yang lebih besar. Oleh karena itu, sulfur dengan ukuran partikel lebih kecil dari 500 mesh atau dengan konsentrasi yang lebih tinggi dari $4 \%$ berpotensi untuk memberikan toksisitas kontak yang lebih tinggi ke larva $S$. frugiperda. 


\section{SIMPULAN}

Hasil penelitian menunjukkan bahwa ukuran partikel mineral sulfur ukuran 500 mesh dapat menyebabkan mortalitas larva $S$. frugiperda pada 1 - 24 hari setelah perlakuan $(11,25 \%$ - 33,75\%) yang berbeda nyata dengan kontrol $(0,00 \%)$. Namun berbagai ukuran partikel mineral sulfur yang diuji tidak memengaruhi lama perkembangan larva dan berat pupa $S$. frugiperda. Sementara itu, perlakuan mineral sulfur ukuran 100, 400, dan 500 mesh mampu memengaruhi kemunculan imago normal $S$. frugiperda dibandingkan dengan kontrol air.

\section{UCAPAN TERIMA KASIH}

Ucapan terima kasih Penulis sampaikan kepada semua pihak yang terlibat dalam penelitian ini. Ucapan terima kasih juga Penulis sampaikan kepada Kementerian Pertanian yang telah memberikan bantuan Pendidikan melalui Beasiswa Tugas Belajar PNS.

\section{DAFTAR PUSTAKA}

Alcala-Orozco, M, K Caballero-Gallardo, and J Olivero-Verbel. 2020. Intergenerational effects of coal dust on Tribolium castaneum, Herbst. Environmental Research. 182-109055.

Alkan, M, S Ertürk, T Atay, and A Çağlayan. 2019. Insecticidal efficacy of local diatomaceous earths against adult and larvae of Tenebrio molitor L., 1758 (Coleoptera: Tenebrionidae)1. Turkiye Entomoloji Dergisi. 43(3): 347-454.

Bonne, C, C Bond, A Cross, and J Jenkins. 2017. Sulfur general fact sheet. Environmental Protection. Available online at npic.orst.edu/factsheets/sulfurgen.html. Accessed October 2021.

Capinera, JL. 2017. Fall armyworm, Spodoptera frugiperda (J.E. Smith). IFAS Extension, 1-6. http://entnemdept.ufl.edu/creatures/field/fall _armyworm.htm

Constanski, KC, J Zorzetti, PH Santoro, AT Hoshino, and PMOJ Neves. 2016. Inert powders alone or in combination with neem oil for controlling Spodoptera eridania and Spodoptera frugiperda (Lepidoptera: Noctuidae) larvae. Semina: Ciencias Agrarias. 37(4): 1801-1810.

Das, SK, S Podder, and S Roy. 2010. Effect of fungicide, Thiovit ${ }^{\circledR}$ Jet on several life history trait of Drosophila melanogaster (Diptera:
Drosophilidae). Journal of Applied Biological Sciences. 4(3): 31-36.

Dickinson, BC, CM Meadows, and ED Witman. 1941. Sulfur as a stomach insecticide1. Journal of Economic Entomology. 34(5): 656-659.

ESPI Metals. 2017. Understanding Mesh Sizes. Available online at https://www.espimetals.com/index.php/faq/3 34-understanding. Accessed October 2021.

FAOSTAT. 2020. Crops and Livestock Products. Food and Agriculture Organization of the United Nations. Available online at https://www.fao.org/faostat/en/\#data/QCL. Accessed October 202.

Gardner-Gee, R. 2013. Sulphur reduces egglaying in laboratory trials with tomato potato psyllid (Bactericera cockerelli). New Zealand Plant Protection. 66: 386-386.

Glenn, DM, GJ Puterka, T Vanderzwet, RE Byers, and C Feldhake. 1999. Hydrophobic particle films: A new paradigm for suppression of arthropod pests and plant diseases. Journal of Economic Entomology. 92(4): 759-771.

Glenn, DM, and GJ Puterka. 2010. Particle films: A new technology for agriculture. Horticultural Reviews. 31: 1-44.

Guerreiro, JC, PH Camolese, and AC Busoli. 2013. Eficiência de inseticidas associados a enxofre no controle de Spodoptera frugiperda em milho convencional. Scientia Agraria Paranaensis. 12(4): 275-285.

Hua, KH, HC Wang, RS Chung, and JC Hsu. 2015. Calcium carbonate nanoparticles can enhance plant nutrition and insect pest tolerance. Journal of Pesticide Science. 40(4): 208-213.

Kementerian Pertanian. 2020. Rencana Strategis Kementerian Pertanian 2020-2024. Kementerian Pertanian. Tersedia online pada https://www.pertanian.go.id/home/?show=pa ge\&act=view\&id=12. Diakses Agustus 2021.

Korunić, Z. 1997. Rapid assessment of the insecticidal value of diatomaceous earths without conducting bioassays. Journal of Stored Products Research. 33(3): 219-229.

Kuribayashi, S. 1988. Damage of silkworms caused by pesticides and preventive measures. JARQ. Japan Agricultural Research Quarterly. 21(4): 274-283.

Lestari, P, A Budiarti, Y Fitriana, F Susilo, IG Swibawa, H Sudarsono, R Suharjo, AM Hariri, Purnomo, Nuryasin, Solikhin, L Wibowo, Jumari, dan M Hartaman. 2020. Identification 
and genetic diversity of Spodoptera frugiperda in Lampung Province, Indonesia. Biodiversitas, 21(4): 1670-1677.

Netto, AFA. 2020. Enxofre Como Desalonjante Para Spodoptera frugiperda, Incluindo Consideracoes Sobre Sua Mistura Com O Insecticida Espinosade, Em Plantas De Milho Doce. [Dissertação]. Programa de PósGraduação em Olericultura. Morrinhos.

Nonci, N, SH Kalgutny, H Mirsam, A Muis, M Azrai, and M Aqil. 2019. Pengenalan Fall Armyworm (Spodoptera frugiperda J.E. Smith) Hama Baru pada Tanaman Jagung di Indonesia. Badan Penelitian dan Pengembangan Pertanian Balai Penelitian Tanaman Serealia. Maros.

Oktianty, R, Martini, dan R Rully. 2016. Efektivitas fumigan sulfuryl fluoride terhadap pengendalian Tribolium castaneum (Insecta : Coleoptera) di gudang industri pakan ternak di wilayah Kota Semarang. Jurnal Kesehatan Masyarakat (e-Journal). 4(1): 188-192.

Pérez-Guerrero, S, and JM Molina. 2016. Laboratory approach to the use of sulphur and kaolin as preventive control against Drosophila suzukii. Spanish Journal of Agricultural Research. 14(2): 1-6.

Prayogo, Y. 2017. Perbandingan metode aplikasi jamur entomopatogen Beauveria bassiana untuk pengendalian Cylas formicarius (Coleoptera: Curculionidae). 17(1): 84-95.

Riudavets, J, MJ Pons, R Gabarra, C Castañé, O Alomar, LF Vega, and S Guri. 2014. The toxicity effects of atmospheres with high content of carbon dioxide with addition of sulphur dioxide on two stored-product pest species: Sitophilus oryzae and Tribolium confusum. Journal of Stored Products Research. 57: 58-62.

Saenong, MS. 2017. Tumbuhan Indonesia potensial sebagai insektisida nabati untuk mengendalikan hama kumbang bubuk jagung (Sitophilus spp.). Jurnal Penelitian Dan Pengembangan Pertanian. 35(3): 131-142.

Sartiami, D, Dadang, IS Harahap, YM Kusumah, and
R Anwar. 2020. First record of fall armyworm (Spodoptera frugiperda) in Indonesia and its occurence in three provinces. IOP Conference Series: Earth and Environmental Science. 468012021.

Smith, RF, and GF MacLeod. 1943. Alfalfa butterfly control with sulphur dusts1, 2, 3. Journal of Economic Entomology. 36(5): 665-671.

Suarni, dan M Yasin. 2015. Jagung sebagai sumber pangan fungsional. Iptek Tanaman Pangan. 6(1): 41-56.

Subiono, T. 2019. Preferensi Spodoptera frugiperda (Lepidoptera: Noctuidae) pada beberapa sumber pakan. Jurnal Groekoteknologi Tropika Lembab. 2(2): 130-134.

Subiyakto, N Asbani, DA Sunarto, dan Sujak. 2016). Efikasi pestisida alami kalsium polisulfida (sulfur) terhadap tungau (Polyphagotarsoneum latus L.). Agrovigor. 9(1): 42-47.

Syuryawati, A Biba, dan H Subagio. 2014. Produksi dan pemasaran benih jagung di Nusa Tenggara Barat menunjang kemandirian pangan. Prosiding Seminar Nasional Hari Pangan Sedunia Ke-34 Pertanian-Bioindustri Berbasis Pangan Lokal Potensial. Makassar, 4 November 2014. Hlm. 421-429.

USDA. 2017. Sulfur Livestock. Technical Evaluation Report. Available online at https://www.ams.usda.gov/sites/default/files/ media/SulfurLivestockTR.pdf.

Utomo, S. 2012. Dampak impor dan ekspor jagung terhadap produktivitas jagung di Indonesia. Etikonomi. 11(2): 158-179.

Vayias, BJ, CG Athanassiou, Z Korunic, and V Rozman. 2009. Evaluation of natural diatomaceous earth deposits from southeastern Europe for stored-grain protection: The effect of particle size. Pest Management Science. 65(10): 1118-1123.

Williams, JS, and RM Cooper. 2004. The oldest fungicide and newest phytoalexin - A reappraisal of the fungitoxicity of elemental sulphur. Plant Pathology. 53(3): 263-279. 